\title{
Isolation of Cellulose Degrading Bacteria from Indoor, Outdoor and Soil Environment
}

\author{
Legese Hagos \\ Ethiopian Institute of Agricultural Research, Jimma Agricultural Research Center
}

\begin{abstract}
Cellulose is the most abundant organic polymer on Earth and is an important structural component of the primary cell wall of green plants. Cellulose should be degraded and converted to into soil and recycled through the activity of microorganisms. Bacteria play important role to degrade cellulose for their energy requirements to sustain their life. The current study was initiated to isolate and identify Cellulose Degrading Bacteria from indoor, outdoor and Cellulose rich soil by using Methyl Cellulose Agar media. Three Petri dishes with three replication both heat boiled and autoclaved containing culture media, from indoor air, outdoor air and soil has been tested for their effective Cellulose degrading bacterial growth ability. Cellulose degrading bacteria has been isolated with providing Methyl Cellulose only as carbon source. The Autoclaved outdoor air shown best result with fast growth and many bacterial colony following indoor and soil samples. These cellulose degrading bacteria has been tested for their Gram test, Catalase test, motility test and carbohydrate consumption tests and shown Gram positive as well as the rest tests were also positive results. Therefore, isolation and application of cellulose degrading bacteria will have great benefits in terms of degrading pollutants from the environment.
\end{abstract}

Keywords:Cellulose, Cellulose degrading bacteria, Methyl Cellulose Agar

DOI: $10.7176 / \mathrm{JEES} / 11-11-01$

Publication date: November $30^{\text {th }} 2021$

\section{Introduction}

Cellulose is a linear polysaccharide which is the most abundance on the existing earth (Gupta et al., 2012). it is a combination from units of glucose monomer and is constituent of plant cell wall. It constitutes the main part of dietary fiber from several polysaccharides. Specifically cellulose is one of the components of insoluble fiber. Cellulase is an enzyme which synthesized by a number of microorganisms on their growth either by cell-bound or extra cellular (Lee and Koo, 2001) and is an enzymes produced mainly by fungi, bacteria, and protozoa that catalyze cellulolysis. The degradation of cellulose is naturally conducted by microorganisms using multi-enzyme complex (Aubert et al, 1987).

The enzyme system have three classes of soluble extracellular enzymes: $1,4-\beta$-endoglucanase, $1,4-\beta$ exoglucanase, and $\beta$-glucosidase ( $\beta$-D-glucoside glucohydrolase or cellobiase). It is the responsiblity of Endoglucanase for the cleavage of $\beta-1,4$-glycosidic bonds in the chain of cellulose. Exoglucanase is also essential for cleavage of the nonreducing end of a cellulose chain and splitting of the elementary fibrils from the crystalline cellulose, and $\beta$-1, 4-glucosidase hydrolyses cellobiose and water-soluble cellodextrin to glucose (Shewale, 1982; Woodward and Wiseman, 1982).

Based on the reaction they catalyse, Cellulase enzymes are classified in to five general types. These are Endocellulase, Exocellulase, Cellobiase or beta-glucosidase, Oxidative cellulasesR and Cellulose phosphorylases. They are important enzymes for the industrial process and application (Hanif et al., 2004; Jamil et al., 2005). Cellulase are applicable in many industries from which the major ones are in textile industry for bio polishing of fabrics and producing stonewashed look of denims, as well as in household laundry detergents for improving fabric softness and brightness (Kanokphorn, 1998). moreover there are certain microorganism that can use cellulose as a sole source of energy and by doing they can be able to utilized and make use of it and cellulose is degrading by such microorganism. In addition to this, different microbiological technique and media are employed to isolate and characterizes cellulose degrading microorganisms from soil sample and air exposure environment.

Cellulose degrading microbes are playing a great role in bioremediation activities by converting the organic matter of plant debris and papers coming out from industries and municipal wastes. To facilitate the decomposition of these wastes, introduction of particular cellulose degrading microbes is essential for both insitu and ex-situ conditions. Little information is known about cellulose degrading microbes. The current study was initiated to isolate and characterize effective cellulose degrading bacteria by using Methyl cellulose agar.

\author{
Material and method \\ The study site and period \\ The study was conducted in Jimma town, which is located at $333 \mathrm{~km}$ Southwest of Addis Ababa, Ethiopia.
}




\section{Isolation of Cellulose degrading microorganism}

Culture media has been prepared by measuring $15 \mathrm{~g}$ Methyl cellulose and $15 \mathrm{~g}$ Agar for $1000 \mathrm{ml}$ of sterilized distilled water and mixed together in a flak. The half of prepared media was allowed to heat boil and the remaining half allowed to autoclave at $121^{\circ} \mathrm{C}$. Twenty $\mathrm{ml}$ of sterilized medium was poured to sterilized petridishes and allowed to cool to solidify for 30 minutes. After the media has solidified, three petridishes containing media from both heat boiled and autoclaved allowed to be opened for $15 \mathrm{~min}$ in both indoor and outdoor environment to get microbes in to the media from the air. After 15 minutes the petridishes were covered. A gram of soil weighed and diluted in $9 \mathrm{ml}$ distilled water serially. Then $0.5 \mathrm{ml}$ of sample has been transferred to another new both heat boiled and autoclaved media containing petridishes. Finally the whole media containing air and soil samples with negative control that petridishes with only sterilized media has been placed in incubator at $30^{\circ} \mathrm{c}$.

\section{Characterization of Cellulolytic Bacteria}

For characterization of cellulose degrading bacteria, triple sugar iron broth, SIM and simon for media has been prepared for glucose, lactose, sucrose utilization and motility test.

\section{Result and Discussion}

Biochemical characterization of cellulose degrading microorganisms

Biochemical test was carry out to test for motility, catalase, glucose and citrate utilization . These test were subjected to different broth SIM, Triple Sugar Iron and Simon for citrate utilization and below are the biochemical characterization of cellulose degrading bacteria

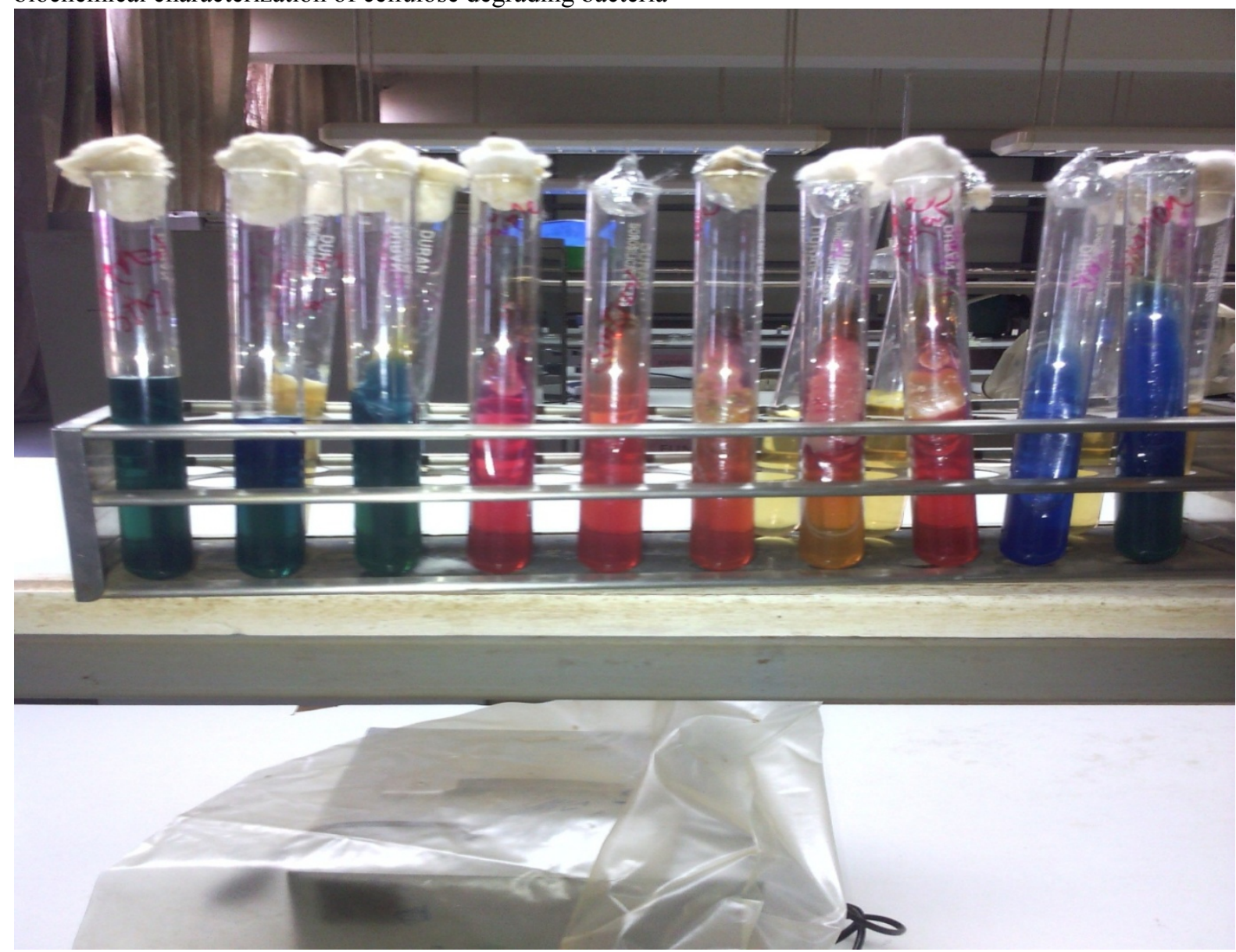

Fig. Biochemical tests of Cellulose degrading bacteria

Result of Isolated cellulose degrading microorganism and their response for different tests

The isolates were tasted for catalase, motility, citrate and gram tests indicated that they do have positive reactions. 
Table. Biochemical test results of bacterial isolates test

\begin{tabular}{|c|c|c|c|c|c|}
\hline \multicolumn{6}{|c|}{ Biochemichal reaction test } \\
\hline Sample & & & & & \\
\hline Isolate & Catalase & Motility & Citrate & Glucose & $\begin{array}{l}\text { Gram } \\
\text { test }\end{array}$ \\
\hline Isolate od & + & + & + & + & + \\
\hline Isolate In & + & + & + & + & + \\
\hline Isolate Soil & + & + & + & + & + \\
\hline
\end{tabular}

Where: od=outdoor, in=indoor, soil=soil, $+=$ positive, $-=$ negative

\section{Discussion}

Cellulose degrading bacteria has been detected from indoor, outdoor and soil samples on Methyl cellulose Agar media. The result indicated that after 5 days incubation the autoclaved media from outdoor isolate shown fast growth and many bacterial colonies has been observed followed autoclaved media from indoor, heat boiled media from outdoor, heat boil media from indoor and autoclaved media from soil sample respectively. The result indicates that these cellulose degrading bacteria need more time to grow on the media and takes long time which takes from 5 to 10 days to consume methyl cellulose agar media as carbon source. Moreover, samples from outdoor have the opportunity to get many microbes than indoor one because of indoor environment is a little bit controlled while the outdoor one is not controlled and enabled to get more microbes. Samples from soil were lately grown and small in numbers when compared to that of air samples due to needs time to find optimum condition to release callulase enzyme and consume the methyl cellulose agar. The characterization result indicates that the isolated bacteria was gram positive, catalase positive, motility positive, carbohydrate consumption positive. (Gupta et al., 2012) reported that bacterial isolates showed a potential to convert cellulose into reducing sugars which could be readily used in many applications like feed stock for production of valuable organic compounds.

\section{Conclusion}

Cellulose degrading bacteria isolated from outdoor, indoor and soil samples and cellulose methyl agar has been used as only carbon source for these microbes. The samples taken from outdoor showed promising result which is a very good degrading ability and can be isolated and produced in mass for different industrial activities as well as for bioremediation if is studied using appropriate chemicals and characterized to strain level. So that it is vital to search cellulose degrading microorganisms from different sources for the degradation of environmental pollutants.

\section{References}

Aubert JP, Beguin P, Millet J (1987).Biochemistry and Genetics of cellulose degradation, fungal and bacterial enzyme systems and their manipulation. FEMS symposium. Academic press, New York. 43: 11-30.

Gupta P, Samant K, and Sahu A (2011). Isolation of Cellulose-Degrading Bacteria and Determination of Their Celluloytic Potential. International Journal of Microbiology. 15:1-5.

Hanif A, Yasmin A and Rajoka.M.I (2004).Induction, production, repression and de-repression of exoglucanase synthesis in Aspergillusniger. Bioresour. Technol, 94: 311-319.

Jamil, A., Naim, S., Ahmed and Ashraf M (2005). Production of Industrially important enzymes using molecular approaches; cellulases and xylanases. In: Genetic resources and Biotechnology II, Volume 2, (Eds.): D. Thangadurai, T. Pullaiah, Pedro and A. Balatti. Regency publications, New Delhi, 7: 143-183.

Kanokphorn, S., Piyaporn, V., Siripa, J (2011). Isolation of novel cellulose from agricultural soil and application for ethanol production. Int. J. Adv. Biotechnol Res. 2: 230239.

Lee, S.M and Koo, M.Y (2001). Pilot-scale production of cellulose using Trichoderma reeseiRut C-30 infed batch mode. J. Microbiol. Biotechnol. 11: 229233.

Shewale, J.G., 1982. $\beta$-Glucosidase: its role in cellulase synthesis and hydrolysis of cellulose. International Journal of Biochemistry, 14(6), pp.435-443.

Woodward, J. and Wiseman, A., 1982. Fungal and other $\beta$-d-glucosidases-their properties and applications. Enzyme and Microbial Technology, 4(2), pp.73-79. 